\title{
EFEKTIVITAS PEMBELAJARAN DARING MENGGUNAKAN MODEL KOOPERATIF TIPE TEAM ASSISTED INDIVIDUALIZATION (TAI)
}

\author{
Nurqiyamah Hamid ${ }^{1}$, Andi Jusmiana ${ }^{2}$ \\ STKIP YAPTI Jeneponto ${ }^{1}$, Universitas Pejuang Republik Indonesia ${ }^{2}$ \\ qiyahamid@gmail.com ${ }^{1}$, andijusmiana@gmail.com ${ }^{2}$
}

\section{Abstrak}

Penelitian ini bertujuan untuk mengetahui efektivitas model pembelajaran kooperatif tipe Team Assisted Individualization (TAI) dalam pembelajaran jarak jauh atau Dalam Jaringan (Daring). Penelitian ini merupakan Pre-Eksperimental dengan model One Group Pretest Posttest Design dengan sampel sebanyak 27 orang siswa. Treatment penelitian dilaksanakan 8 kali pertemuan menggunakan aplikasi Zoom. Pengumpulan data dilakukan menggunankan aplikasi online dan offline. Tes hasil belajar dan angket respon siswa melalui aplikasi online Google Form. Sedangkan lembar observasi aktivitas siswa, keterlaksanaan pembelajaran, dan keterampilan pembelajaran kooperatif disiapkan dan diisi oleh peneliti. Hasil penelitian menunjukkan bahwa model pembelajaran kooperatif tipe Team Assisted Individualization (TAI) efektif digunakan dalam pembelajaran Daring pada siswa kelas X MAN Binamu Kabupaten Jeneponto, dimana: (1) rata-rata hasil belajar matematika siswa sebesar $85,19 \%$ atau mencapai ketuntasan belajar secara klasikal; (2) Aktivitas positif siswa meningkat dari pertemuan II sampai V. Sedangkan aktivitas negatif siswa dari pertemuan ke-II hingga pertemuan ke-IV menurun adalah berturut-turut 18,51\%, 11,11\%, 11,11\% dan 3,70\%; (3) Respon siswa terhadap pelaksanaan pembelajaran matematika positif dengan persentase yaitu $94,08 \%$ dan sudah memenuhi kriteria yang telah ditetapkan yaitu $75 \%$; (4) Keterlaksanaan pembelajaran berada pada kategori baik; dan (5) Keterampilan pembelajaran kooperatif siswa lebih banyak yang berada pada kategori sedang/cukup.

Kata Kunci: Pembelajaran, Daring, Kooperatif, Team Assisted Individualization (TAI)

\section{A. Pendahuluan}

Pada awal tahun 2020, Organisasi Kesehatan Dunia atau World Health Organization (WHO) secara resmi menetapkan Koronavirus 2019-2020 (COVID19) menjadi pandemi global. Akibat penularannya yang begitu cepat, semua negara membatasi ruang gerak setiap penduduknya melalui Physical Distancing. Hal tersebut membawa perubahan drastis bagi seluruh lini kehidupan, khususnya dalam dunia pendidikan. Proses belajar mengajar dilaksanakan secara jarak jauh atau Dalam Jaringan (Daring) (J. Crawford, 2020). 
Terkhusus di Indonesia, Menteri Pendidikan dan Kebudayaan (Mendikbud) menerbitkan Surat Edaran Nomor 4 Tahun 2020 tentang Pelaksanaan Pendidikan Dalam Masa Darurat Coronavirus Disease (Covid-19). Sesuai himbauan resmi tersebut, proses belajar mengajar di seluruh satuan pendidikan dilaksanakan secara Daring atau harus mematuhi protokol kesehatan bagi wilayah bertatus zona hijau. Adapun pembelajaran jarak jauh ini dilaksanakan untuk memberikan pengalaman belajar yang bermakna bagi siswa, tanpa terbebani tuntutan menuntaskan seluruh capaian kurikulum untuk kenaikan kelas maupun kelulusan (Wajdi, 2020).

Oleh karena itu, diperlukan kemampuan profesional guru dalam mengelola dan mengembangkan model pembelajaran yang akan digunakan dalam proses pembelajaran Daring tersebut. Guru-guru di sekolah pada umumnya menggunakan media informasi Whatsapp Group sebagai media dalam pembelajaran daring. Adapun model dan metode yang digunakan guru masih dominan pada pembelajaran klasikal yang bersifat monoton. Akibatnya tujuan pembelajaran sebagai arah dari proses belajar mengajar terkadang tidak sesuai dengan apa yang diharapkan (Zhafira, 2020)

Pada keadaan normal sebelum era Pandemi Covid 19, rendahnya hasil belajar matematika umumnya disebabkan karena siswa kurang minat dan motivasi dalam belajar matematika. Siswa terkadang menganggap bahwa pelajaran matematika adalah pelajaran yang sangat susah dan membosankan sehingga siswa acuh tak acuh terhadap pelajaran matematika. Saat pembelajaran matematika berlangsung siswa kurang memperhatikan dan terkadang hanya sibuk berbicara dengan teman sebangkunya. Siswa juga hanya diam dan jarang ada tanggapan atau pertanyaan akan hal-hal yang tidak dimengerti saat pembelajaran berlangsung (Ayu Ardilla, 2017).

Salah satu model pembelajaran yang paling sering digunakan dalam pembelajaran di sekolah adalah pembelajaran langsung. Pembelajaran matematika secara langsung dan guru sebagai pusat dan sumber belajar merupakan salah satu penyebab kecenderungan siswa untuk menghafal. Berdasarkan segi penguasaan materi, menghafal terbukti berhasil dalam kompetensi belajar jangka pendek, 
tetapi gagal dalam membekali siswa memecahkan persoalan dalam kehidupan jangka panjang (Nopiyani, 2016).

Adapun langkah untuk mengukur keefektifan pembelajaran yaitu dengan empat indikator diantaranya keterlaksanaan pembelajaran, hasil belajar siswa, aktivitas siswa, dan respon siswa. Keterlaksanaan Pembelajaran dapat dinilai melalui kemampuan guru mengelola pembelajaran. Kemampuan tersebut diantaranya: 1) Merencanakan program belajar mengajar; 2) Melaksanakan dan memimpin/mengelola proses belajar mengajar; 3) Menilai kemajuan proses belajar mengajar; dan 4) menguasai bahan pelajaran dalam pengertian menguasai bidang studi atau mata pelajaran yang dipegangnya (Ramadhani, 2016).

Adapun hasil belajar siswa sendiri dapat dibagi menjadi dua kriteria yaitu ketuntasan hasil belajar dan peningkatan skor tes hasil belajar. Ketuntansan hasil belajar siswa penguasaan secara menyeluruh berupa kepandaian atau ilmu (kognitif, afektif, dan psikomotorik) lewat suatu usaha. Peningkatan skor tes hasil belajar ini dapat dilihat dari hasil pretest dan postest. Dimana pretest dan postest itu adalah pemberian tes atau kuis kepada siswa sebelum dan sesudah diberi perlakuan. Jika hasil belajar siswa lebih atau sama dengan Kriteria Ketuntasan Minimum (KKM) maka siswa dinyatakan telah tuntas belajar. Jika prestasi belajar siswa kurang dari KKM maka siswa dikatakan belum tuntas belajar (Aisah, 2015).

Sementara aktivitas siswa yang dimaksud dalam penelitian ini adalah proses komunikasi antara siswa dengan siswa, siswa dengan guru selama proses pembelajaran. Sebab pembelajaran dapat dikatakan efektif jika menghasilkan perubahan tingkah laku selama proses pembelajaran. Selain itu, respon positif siswa juga menjadi salah satu syarat pembelajaran dapat dikatakan efektif, sebab tanggapan merupakan salah satu fungsi kejiwaan yang dapat diperoleh individu setelah pengamatan selesai dilakukan (Puadi, 2020).

Upaya yang dapat dilakukan untuk menciptakan pembelajaran Daring yang efektif yaitu pemilihan model dan metode pembelajaran yang tepat dan tidak monoton. Salah satu model pembelajaran yang melibatkan siswa secara aktif dan dapat meningkatkan hasil belajar adalah model pembelajaran kooperatif tipe Team Assisted Individualization (TAI). Pembelajaran TAI memiliki prosedur yang secara eksplisit lebih banyak memberi kesempatan kepada siswa dalam berpikir, 
menjawab, dan saling membantu satu dengan yang lainnya (N. Noor, 2019). Jadi siswa diharapkan aktif dan mampu merespon materi yang disampaikan oleh guru dan setiap individu juga diajarkan untuk mandiri serta belajar untuk bekerja sama dalam sebuah kelompok.

Dalam penerapannya, Model Pembelajaran Kooperatif Tipe Team Assisted Individualization (TAI) ini memiliki 8 komponen, diantaranya: 1) teams, yaitu pembentukan kelompok heterogen yang terdiri dari 4 sampai 5 siswa; 2) Placement Test, yaitu pemberian pre-test kepada siswa atau melihat raa-rata nilai harian siswa agar guru mengetahui kelemahan siswa pada bidang tertentu; 3) Curriculum Materials, yaitu materi yang dikerjakan oleh siswa sesuai dengan kurikulum yang ada; 4) Team Study, yaitu tahapan tindakan belajar yang harus dilaksanakan oleh kelompok dan guru memberikan bantuan secara individual kebada siswa yang membutuhkan. Siswa diberikan soal secara individual terlebih dahulu kemudian setelah itu mendiskusikan hasilnya dengan kelompok masing-masing; 5) Team Score and Team Recognition, yaitu pemberian score terhadap hasil kerja kelompok dan memberikan criteria penghargaan terhadap kelompok yang berhasil secara cemerlang dan kelompok yag kurang berhasil dalam menyelesaikan tugas; 6) Teaching Group, yaitu pemberian materi secara singkat oleh guru menjelang pemberian tugas kelompok; 7) Fact Test, yaitu pelaksanaan tes-tes kecil berdasarkan fakta yang diperoleh; dan 8) Whole-Class Units, yaitu pemberian materi oleh guru kembali diakhir waktu pembelajaran dengan strategi pemecahan masalah.

Selain itu, efektifvitas pembelajaran kooperatif juga dapat dinilai dari keterampilan pembelajaran kooperatif dalam proses pembelajaran, yaitu: 1) keterampilan kooperatif tingkat awal meliputi: (a) Mengambil giliran dan berbagi tugas; (b) Menyelesaikan tugas tepat pada waktunya; dan (c) Menghormati pendapat individu; 2) Keterampilan kooperatif tingkat menengah, meliputi: (a) menunjukkan penghargaan dan simpati; b) menggunakan ketidaksetujuan dengan cara yang dapat diterima; c) mendengarkan dengan aktif; dan c) bertanya; 3) Keterampilan kooperatif tingkat mahir, meliputi: a) Memeriksa secara cermat; dan b) Menanyakan kebenaran (Hamzah Upu, 2016). 


\section{B. Metode Penelitian}

Penelitian ini adalah penelitian pre-eksperimen yang melibatkan satu kelas sebagai kelas eksperimen. Sampel penelitian sebanyak 27 siswa kelas VIII MA Al Amanah Kabupaten Jeneponto Kabupaten Jeneponto. Penelitian menggunakan desain One Group Pretest-Posttest Design dengan gambaran sebagai berikut:

Skema Desain Penelitian

\begin{tabular}{|c|c|c|}
\hline Pretest & Treatment & Postest \\
\hline $\mathrm{O}_{1}$ & $\mathrm{X}$ & $\mathrm{O}_{2}$ \\
\hline \multicolumn{2}{|c|}{ (Sugiyono, 2013:1/1) } \\
\hline \multicolumn{2}{|c|}{}
\end{tabular}

Keterangan: $\mathrm{X}=$ Treatment (perlakuan) yang diberikan

$\mathrm{O}_{1}=$ Nilai Pertest (sebelum diberi perlakuan)

$\mathrm{O}_{2}=$ Nilai Postest (sesudah diberi perlakuan)

$\left(\mathrm{O}_{2}-\mathrm{O}_{1}\right)=$ Pengaruh perlakuan terhadap hasil belajar.

Treatment dilaksanakan dengan metode daring dan luring. Metode daring dengan menggunakan aplikasi Zoom, dengan pusat kontrol (host) ada pada guru. Sedangkan metode luring dilakukan oleh sesame siswa berdasarkan kelompoknya (4-5 orang). Tiap kelompok difasilitasi masing-masing 1 (satu) akun zoom dan perangkat pembelajaran yang dibutuhkan dalam penerapan model pembelajaran kooperatif tipe TAI. Masing-masing kelompok juga didampingi oleh masingmasing pembantu peneliti (observer).

Adapun Pretest dan Posttest melalui Google Form. Tes dilaksanakan untuk mengukur kemampuan belajar siswa setelah pembelajaran Daring melalui model kooperatif tipe Team Assisted Individualization (TAI). Penskoran hasil tes siswa menggunakan skala bebas yang tergantung dari bobot butir soal tersebut.

Untuk memperoleh data mengenai aktivitas siswa, keterampilan pembelajaran kooperatif dan keterlaksanaan pembelajaran selama proses pembelajaran, peneliti menggunakan lembar observasi atau pengamatan. Sedangkan, respon siswa terhadap proses pembelajaran dinilai dengan menggunakan teknik pemberian angket secara online yaitu melalui aplikasi Google Form.

Lembar observasi keterlaksanaan pembelajaran disusun berdasarkan 4 kategori yaitu kurang (nilai 1), cukup (nilai 2), baik (nilai 3), dan sangat baik (nilai 
4). Indikator yang digunakan untuk mengungkap kemampuan guru mengelola pembelajaran didasarkan pada kegiatan yang dilakukan guru dalam proses pembelajaran sesuai dengan yang direncanakan dalam RPP.

Adapun lembar observasi keterampilan kooperatif dalam pembelajaran berdasarkan 4 kategori, yaitu rendah (nilai 1), cukup/sedang (nilai 2), baik (nilai 3), dan sangat baik (nilai 4), pada kolom yang sesuai menyangkut pengelolaan kegiatan belajar mengajar.

Untuk keperluan pengujian hipotesis, maka terlebih dahulu dilakukan uji statistik dengan menggunakan program SPSS. Dari hasil pengolahan data tersebut, dilakukan penarikan kesimpulan dengan uji hipotesis berikut:

a) Jika taraf $p$-value $>\alpha$ maka $\mathrm{H}_{0}$ diterima dan $\mathrm{H}_{1}$ ditolak berarti tidak ada perbedaan hasil belajar siswa sebelum dilakukan penelitian (pretest) dan setelah dilakukan pembelajaran tipe Team Assisted Individualization (TAI) (posttest) pada siswa di Kabupaten Jeneponto.

b) Jika taraf $p$-value $<\alpha$ maka $\mathrm{H}_{0}$ ditolak dan $\mathrm{H}_{1}$ diterima berarti hasil belajar siswa sebelum dilakukan penelitian (pretest) lebih kecil dari pada hasil belajar siswa setelah dilakukan pembelajaran tipe Team Assisted Individualization (TAI) (posttest) pada siswa di Kabupaten Jeneponto.

\section{Hasil Penelitian dan Pembahasan}

Hasil penelitian ini menunjukkan data hasil belajar siswa pada Kelas X MA Al Amanah Kabupaten Jeneponto sebelum dan setelah dilakukan perlakuan pada pokok bahasan Sistem Persamaan dan Pertidaksamaan Linear ditunjukkan hasil dalam Tabel 1 berikut.

Tabel 1 Statistik Skor Hasil Belajar Matematika Siswa Berdasarkan Hasil Pretest dan Posttest

\begin{tabular}{ccc}
\hline Statistik & \multicolumn{2}{c}{ Nilai Statistik } \\
\cline { 2 - 3 } & Pretest & Posttest \\
\hline Ukuran Sampel & 27 & 27 \\
Skor Tertinggi & 80 & 95 \\
Skor Terendah & 35 & 70 \\
Skor Ideal & 100 & 100 \\
Rentang Skor & 45 & 25 \\
Skor Rata-rata & 55,93 & 79,63 \\
Standar Deviasi & 12,48 & 6,34 \\
\hline
\end{tabular}


Dari Tabel 1 di atas dapat dinyatakan bahwa skor rata-rata siswa setelah perlakuan (Posttest) mengalami peningkatan dari sebelum perlakuan (Pretest) dimana skor rata-rata pretest adalah 55,93 dengan rentang skor 45 sedangkan skor rata-rata posttest adalah 79,63 dengan rentang skor 25 .

Hasil pretest dan postest dikelompokkan ke dalam lima kategori, sehingga diperoleh distribusi frekuensi dan persentase skor yang ditunjukkan pada Tabel 2 berikut:

Tabel 2 Distribusi dan Persentase Skor Hasil Belajar Matematika

\begin{tabular}{ccccccc}
\hline \multirow{2}{*}{ No } & $\begin{array}{c}\text { Indikator } \\
\text { Skor }\end{array}$ & Kategori & Frekuensi & $\begin{array}{c}\text { Presentase } \\
(\%)\end{array}$ & Frekuensi & $\begin{array}{c}\text { Presentase } \\
(\%)\end{array}$ \\
\cline { 4 - 7 } & & Sangat rendah & 9 & 33,33 & 0 & 0 \\
1 & $0-54$ & Rendah & 15 & 55,56 & 4 & 14,81 \\
2 & $55-74$ & 2 & 7,41 & 6 & 22,22 \\
3 & $75-79$ & Sedang & 1 & 3,70 & 15 & 55,56 \\
4 & $80-89$ & Tinggi & 0 & 0 & 2 & 7,41 \\
5 & $90-100$ & Sangat tinggi & 27 & 100 & 27 & 100
\end{tabular}

Skor rata-rata hasil belajar matematika siswa (hasil pretest) sebesar 55,93 dengan standar deviasi 12,48 dari skor ideal 100 berada pada kategori rendah. Ini berarti pada umumnya siswa yang menjadi unit penelitian hasil belajar matematikanya adalah rendah. Sedangkan skor rata-rata hasil belajar matematika siswa (Posttest) sebesar 79,63 dengan standar deviasi 6,34 dari skor ideal 100 berada pada kategori tinggi. Ini berarti pada umumnya siswa yang menjadi unit penelitian hasil belajar matematikanya adalah kategori tinggi.

Selanjutnya untuk melihat persentase ketuntasan belajar matematika siswa (Afriani 2014: 33), sebelum perlakuan (Pretest) dan setelah perlakuan (Posttest) dapat dilihat pada Tabel 3 berikut.

Tabel 3 Deskripsi Ketuntasan Belajar Matematika Siswa Kelas X MA Al Amanah Kabupaten Jeneponto

\begin{tabular}{cccccc}
\hline \multirow{2}{*}{ Skor } & Kategorisasi & \multicolumn{2}{c}{ Pretest } & \multicolumn{2}{c}{ Posttest } \\
\cline { 3 - 6 } & Frekuensi & $\begin{array}{c}\text { Presentase } \\
(\%)\end{array}$ & Frekuensi & $\begin{array}{c}\text { Presentase } \\
(\%)\end{array}$ \\
\hline $75-100$ & Tuntas & 3 & 11,11 & 23 & 85,19 \\
\hline $0-74$ & Tidak Tuntas & 24 & 88,89 & 4 & 14,81 \\
\hline \multicolumn{2}{c}{ Jumlah } & 27 & 100 & 27 & 100 \\
\hline
\end{tabular}

Tabel 3 di menunjukkan bahwa sebelum perlakuan (Pretest) ada 3 orang atau $11,11 \%$ siswa mencapai ketuntasan belajar, dan 24 orang atau 88,89\% siswa lain tidak mencapai ketuntasan belajar. Sedangkan data hasil tes setelah perlakuan 
(Posttest) menunjukkan sebanyak 23 orang atau 85,19\% siswa mencapai ketuntasan belajar, dan 4 orang atau 14,81\% siswa lainnya tidak mencapai ketuntasan belajar.

Berdasarkan hasil pretest dan posttest tersebut, didapatkan hasil uji normalitas menggunakan program Statistical Package for Social Science (SPSS) versi 22 yaitu melalui uji One Sample Kolmograv-Smirnov.

Tabel 4 Hasil Uji Normalitas Skor Pretest dan Posttest Siswa

\begin{tabular}{lcccccc}
\hline & \multicolumn{3}{c}{ Kolmogorov-Smirnov $^{\mathrm{a}}$} & \multicolumn{3}{c}{ Shapiro-Wilk } \\
& Statistic & df & Sig. & Statistic & df & Sig. \\
\hline Pretest & .146 & 27 & .143 & .945 & 27 & .163 \\
\hline Posttest & .153 & 27 & .106 & .929 & 27 & .064 \\
\hline
\end{tabular}

Hasil analisis skor pretest menunjukkan nilai p-value $>\alpha$ yaitu $0,143>$ 0,05 dan skor posttest menunjukkan nilai p-value $>\alpha$ yaitu $0,106>0,0$. Hal ini menunjukkan bahwa skor pretest dan skor posttest siswa berdistribusi normal.

Hipotesis dalam penelitian ini diuji dengan menggunakan statistik Uji-t. Pengujian menggunakan uji satu pihak (pihak kanan) dengan tingkat signifikansi $\alpha$ $=5 \%$ atau $\alpha=0,05$. Kriteria pengujian yaitu:

$\mathrm{H}_{0}$ diterima jika $P$-value $>\alpha$.

$\mathrm{H}_{0}$ ditolak jika $P$-value $<\alpha$.

Tabel 5 Hasil Uji Normalitas Skor Pretest dan Posttest Siswa

\begin{tabular}{|c|c|c|c|c|c|c|}
\hline & \multicolumn{6}{|c|}{ Test Value $=75$} \\
\hline & \multirow[t]{2}{*}{$\mathrm{t}$} & \multirow[t]{2}{*}{$\mathrm{df}$} & \multirow[t]{2}{*}{$\begin{array}{l}\text { Sig. (2- } \\
\text { tailed) }\end{array}$} & \multirow[t]{2}{*}{$\begin{array}{c}\text { Mean } \\
\text { Difference }\end{array}$} & \multicolumn{2}{|c|}{$\begin{array}{l}95 \% \text { Confidence } \\
\text { Interval of the } \\
\text { Difference }\end{array}$} \\
\hline & & & & & Lower & Upper \\
\hline Pretest & -7.939 & 26 & .000 & -19.07407 & -24.0124 & -14.1357 \\
\hline Posttest & 3.792 & 26 & .001 & 4.62963 & 2.1202 & 7.1391 \\
\hline \multicolumn{7}{|c|}{$\begin{array}{l}\text { Karena } p \text {-value }<\alpha \text { yaitu } 0,001<0,05 \text {, maka } \mathrm{H}_{0} \text { ditolak. Sehingga dapat } \\
\text { apulkan bahwa pembelajaran Daring menggunakan model pembelajaran } \\
\text { eratif tipe Team Assisted Individualization (TAI) efektif digunakan dalam } \\
\text { ngkatan hasil belajar siswa. }\end{array}$} \\
\hline
\end{tabular}

\section{Keterlaksanaan Pembelajaran}

Aspek yang diamati pada keterlaksanaan pembelajaran matematika dengan model pembelajaran kooperatif tipe Team Assisted Individualization (TAI) meliputi beberapa aspek, Aspek-aspek tersebut diamati langsung oleh observer selama proses pembelajaran berlangsung yang dimulai dari pertemuan II sampai 
dengan pertemuan V. Hasil pengamatan terhadap keterlaksanaan pembelajaran matematika dengan model pembelajaran kooperatif tipe Team Assisted Individualization (TAI) diperlihatkan pada Tabel 6 berikut.

Tabel 6 Data Keterlaksanaan Pembelajaran Matematika Model Kooperatif Tipe Team Assisted Individualization (TAI).

\begin{tabular}{|c|c|c|c|}
\hline No & Aspek Pengamatan & Rata-rata & Kategori \\
\hline 1 & Membuka pelajaran dengan salam & 3,5 & Baik \\
\hline 2 & Mengecek kehadiran dan mempersiapkan siswa untuk belajar & 3,5 & Baik \\
\hline 3 & Menyampaikan tujuan pembelajaran yang akan dicapai & 3,25 & Baik \\
\hline 4 & $\begin{array}{l}\text { memberikan tes penempatan (Placement Test) kepada siswa } \\
\text { pada awal pembelajaran }\end{array}$ & 3,0 & Baik \\
\hline 5 & Menjelaskan kepada siswa materi yang akan dipelajari & 4,0 & Sangat baik \\
\hline 6 & $\begin{array}{l}\text { Memberikan kesempatan kepada siswa untuk menanyakan } \\
\text { hal-hal yang belum dimengerti }\end{array}$ & 4,0 & Sangat baik \\
\hline 7 & $\begin{array}{l}\text { mengorganisir siswa kedalam beberapa kelompok heterogen } \\
\text { (berdasarkan nilai dari tes penempatan (Placement Tes), } \\
\text { agama, ras, dan jenis kelamin) yang beranggotakan } 4 \text { - } 5 \\
\text { orang. }\end{array}$ & 3,25 & Baik \\
\hline 8 & $\begin{array}{l}\text { Membagikan LKS kepada setiap siswa dalam setiap } \\
\text { kelompok. }\end{array}$ & 3,0 & Baik \\
\hline 9 & $\begin{array}{l}\text { Memberi kesempatan kepada setiap siswa untuk } \\
\text { menyelesaikan LKS secara individu. }\end{array}$ & 3,75 & Baik \\
\hline 10 & $\begin{array}{l}\text { Memberikan bantuan kepada siswa yang membutuhkan pada } \\
\text { saat mengerjakan tugas }\end{array}$ & 4,0 & Sangat baik \\
\hline 11 & $\begin{array}{l}\text { Memberi kesempatan kepada setiap kelompok untuk } \\
\text { mendiskusikan jawaban yang layak di persentasikan. }\end{array}$ & 3,5 & Baik \\
\hline 12 & $\begin{array}{l}\text { Meminta perwakilan setiap kelompok untuk } \\
\text { mempresentasikan hasil kerjanya }\end{array}$ & 3,25 & Baik \\
\hline 13 & $\begin{array}{l}\text { Memberikan penghargaan kepada siswa secara kelompok } \\
\text { maupun secara individu }\end{array}$ & 4,0 & Sangat baik \\
\hline 14 & $\begin{array}{l}\text { Menyampaikan materi yang akan di pelajari pada pertemuan } \\
\text { berikutnya }\end{array}$ & 3,5 & Baik \\
\hline \multirow[t]{2}{*}{15} & Mengakhiri pertemuan dengan salam & 3,25 & Baik \\
\hline & Rata-rata & 3,5 & Baik \\
\hline
\end{tabular}

Berdasarkan Tabel 6 di atas, keterlaksanaan pembelajaran matematika dengan model pembelajaran kooperatif tipe Team Assisted Individualization (TAI) untuk setiap indikator dalam beberapa pertemuan jika dirata-ratakan maka lebih dominan berada pada kategori "baik". Walaupun secara umum keterlaksanaan pembelajaran telah dinyatakan dalam kategori baik, tetapi masih ada beberapa aspek atau fase dalam sintaks pembelajaran model pembelajaran kooperatif tipe Team Assisted Individualization (TAI) yang masih perlu ditingkatkan.

\section{Aktivitas Siswa}


Untuk mengetahui perubahan sikap siswa dalam proses belajar mengajar dapat kita lihat pada hasil observasi aktivitas siswa yang dilakukan pada setiap pertemuan selama pembelajaran matematika melalui model pembelajaran kooperatif tipe Team Assisted Individualization (TAI) berlangsung pada tiap pertemuan dicatat beberapa siswa yang hadir pada saat pembelajaran, siswa yang mengajukan pertanyaan mengenai materi yang belum dipahami, siswa yang menjawab/menanggapi pertanyaan dari teman/guru, siswa yang meminta bimbingan/bantuan dalam mengerjakan soal-soal latihan LKS, dan lain sebagainya seperti yang tercantum dilembar observasi.

Berikut ini data hasil observasi aktivitas siswa yang digunakan untuk mengetahui aktivitas siswa selama pembelajaran matematika melalui model pembelajaran kooperatif tipe Team Assisted Individualization (TAI) pada siswa kelas X MA Al Amanah Kabupaten Jeneponto.

Tabel 7 Hasil Observasi Aktivitas Siswa Kelas X MA Al Amanah Kabupaten Jeneponto melalui Pembelajaran Daring menggunkan model kooperatif tipe Team Assisted Individualization (TAI)

\begin{tabular}{|c|c|c|c|c|c|c|c|c|c|}
\hline \multirow[t]{2}{*}{ No } & \multirow[t]{2}{*}{$\begin{array}{c}\text { Aspek Pengamatan Aktivitas } \\
\text { Siswa }\end{array}$} & \multicolumn{4}{|c|}{$\begin{array}{c}\text { Frekuensi Aktivitas } \\
\text { Siswa pada } \\
\text { Pertemuan ke- } \\
\end{array}$} & \multicolumn{4}{|c|}{$\begin{array}{l}\text { Persentase Aktivitas Siswa } \\
\text { pada Pertemuan ke- }\end{array}$} \\
\hline & & II & III & IV & $\mathrm{V}$ & II & III & IV & V \\
\hline 1 & $\begin{array}{l}\text { Mengajukan pertanyaan mengenai } \\
\text { materi yang belum dipahami }\end{array}$ & 9 & 11 & 8 & 11 & 33,33 & 40,74 & 29,63 & 40,74 \\
\hline 2 & $\begin{array}{l}\text { Menjawab/menanggapi } \\
\text { pertanyaan dari teman/guru }\end{array}$ & 5 & 7 & 8 & 6 & 18,51 & 25,93 & 29,63 & 22,22 \\
\hline 3 & $\begin{array}{l}\text { Meminta bimbingan/bantuan } \\
\text { dalam mengerjakan soal-soal } \\
\text { latihan LKS. }\end{array}$ & 10 & 9 & 7 & 7 & 37,04 & 33,33 & 25,93 & 25,93 \\
\hline 4 & $\begin{array}{l}\text { Memberi bantuan penjelasan } \\
\text { kepada teman yang } \\
\text { membutuhkan. }\end{array}$ & 7 & 5 & 4 & 8 & 25,93 & 18,51 & 14,81 & 29,63 \\
\hline 5 & $\begin{array}{l}\text { Memberi tanggapan terhadap } \\
\text { presentasi dari kelompok lain }\end{array}$ & 6 & 4 & 3 & 5 & 22,22 & 14,81 & 11,11 & 18,51 \\
\hline 6 & $\begin{array}{l}\text { Mengumpulkan/menyetor } \\
\text { pekerjaan rumah }\end{array}$ & 24 & 26 & 25 & 24 & 88,89 & 96,29 & 92,60 & 88,89 \\
\hline 7 & $\begin{array}{l}\text { Siswa yang melakukan aktivitas } \\
\text { lain di luar kegiatan pembelajaran }\end{array}$ & 5 & 3 & 3 & 1 & 18,51 & 11,11 & 11,11 & 3,70 \\
\hline
\end{tabular}

Aktivitas siswa dalam pembelajaran bisa positif ataupun negatif. Aktivitas siswa yang positif dijelaskan pada tabel 4.9 yaitu poin 1 sampai 6 mengalami peningkatan persentase dari pertemuan ke-II hingga pertemuan ke-V . Sedangkan aktivitas siswa yang negatif pada tabel 4.9 yaitu poin 7 siswa melakukan aktivitas lain diluar kegiatan pembelajaran misalnya tidak memperhatikan penjelasan guru, 
bermain, mengganggu teman, mengantuk, tidur, keluar masuk ruangan. Sehingga persentase siswa yang melakukan aktivitas negatif dari pertemuan ke-II hingga pertemuan ke-V menurun adalah berturut-turut 18,51\%, 11,11\%, 11,11\% dan $3,70 \%$.

Dari hasil observasi tersebut terlihat adanya perubahan pola belajar siswa yang menjawab pertanyaan yang diajukan oleh peneliti bertambah, disamping itu mereka juga semakin antusias dan aktif mengerjakan tugas yang diberikan. Aktivitas yang kurang baik pun cenderung berkurang. Seperti siswa yang melakukan kegiatan lain pada saat proses pembelajaran berlangsung. Hal ini menunjukkan adanya perubahan sikap dalam diri siswa.

\section{Respon Siswa}

Hasil analisis data respon siswa terhadap pelaksanaan pembelajaran matematika melalui model pembelajaran kooperatif tipe Team Assisted Individualization (TAI) yang diisi oleh 27 siswa secara singkat ditunjukkan sebagai berikut:

Tabel 8 Data Respon Siswa terhadap Pembelajaran Daring Menggunakan model pembelajaran kooperatif tipe Team Assisted Individualization (TAI)

\begin{tabular}{|c|c|c|c|c|c|}
\hline \multirow[b]{2}{*}{ No } & \multirow[b]{2}{*}{ Aspek yang Direspon } & \multicolumn{2}{|c|}{ Respons Siswa } & \multicolumn{2}{|c|}{ Persentase (\%) } \\
\hline & & $\begin{array}{c}\text { Suka/ } \\
\text { Ya }\end{array}$ & Tidak & Suka/Ya & Tidak \\
\hline 1 & $\begin{array}{l}\text { Menyukai pelajaran daring dengan } \\
\text { menggunakan model pembelajaran kooperatif } \\
\text { tipe Team Assised Individualization (TAI) }\end{array}$ & 25 & 2 & 92,59 & 7,41 \\
\hline 2 & $\begin{array}{l}\text { Memahami materi yang diajarkan oleh guru } \\
\text { melalui model pembelajaran kooperatif tipe } \\
\text { Team Assised Individualization (TAI) }\end{array}$ & 26 & 1 & 96,30 & 3,70 \\
\hline 3 & $\begin{array}{l}\text { Menyukai LKS yang digunakan pada saat } \\
\text { pembelajaran melalui model pembelajaran } \\
\text { kooperatif tipe Team Assised Individualization } \\
\text { (TAI) }\end{array}$ & 23 & 4 & 85,19 & 14,82 \\
\hline 4 & $\begin{array}{l}\text { Menyukai proses belajar mengajar dengan } \\
\text { menggunakan model pembelajaran kooperatif } \\
\text { tipe Team Assisted Individualization (TAI) }\end{array}$ & 26 & 1 & 96,30 & 3,70 \\
\hline 5 & $\begin{array}{l}\text { Pembelajaran kooperatif tipe Team Assisted } \\
\text { Individualization (TAI) dapat meningkatkan } \\
\text { hasil belajar }\end{array}$ & 27 & 0 & 100,00 & 0,00 \\
\hline & Rata-rata & & & 94,08 & 5,93 \\
\hline
\end{tabular}

Dari data tersebut, diperoleh persentase respon siswa dengan menggunakan model pembelajaran kooperatif tipe Team Assised Individualization (TAI), yaitu: (1) siswa yang suka pelajaran matematika sebesar 92,59\%; (2) siswa yang memahami materi yang diajarkan oleh guru sebesar 96,30\%; (3) siswa yang menyukai LKS yang digunakan sebesar 85,19\%; (4) siswa yang menyukai proses 
belajar mengajar sebesar 96,30\%; (5) siswa yang mengaku dapat meningkatkan hasil belajarnya sebesar 100,00\%;

\section{Keterampilan Kooperatif}

Hasil analisis data keterampilan pembelajaran kooperatif siswa terhadap pelaksanaan pembelajaran Daring melalui model pembelajaran kooperatif tipe Team Assisted Individualization (TAI) yang diisi oleh 27 siswa secara singkat ditunjukkan sebagai berikut:

Tabel 9 Persentase Keterampilan Pembelajaran Kooperatif Siswa dalam Pembelajaran Daring Menggunakan Model Pembelajaran Kooperatif Tipe Team Assisted Individualization (TAI)

\begin{tabular}{clcc}
\hline No & Kategori & Jumlah Siswa & Persentase (\%) \\
\hline 1 & Sangat Baik & - & 0 \\
2 & Baik & 2 & 7,41 \\
3 & Cukup Baik & 21 & 77,78 \\
4 & Rendah & 4 & 14,81 \\
5 & Sangat Rendah & - & 0 \\
\hline & Total & 27 & 100 \\
\hline
\end{tabular}

Dalam analisis keterampilan pembelajaran kooperatif setiap siswa maka siswa dinilai oleh observer sesuai dengan aspek-aspek atau bagian-bagian keterampilan pembelajaran kooperatif itu sendiri yang terdiri dari Sembilan aspek. Dari data tersebut dapat diketahui baik atau tidaknya keterampilan pembelajaran kooperatif setiap siswa pada saat mempresentasikan masing-masing kelompoknya. Table 9 di atas menunjukkan bahwa hanya ada 2 siswa yang berada pada kategori "baik", 4 siswa berada pada kategori "rendah", 1 siswa berada pada kategori "Sangat rendah", dan 20 siswa yang berada pada kategori "cukup/sedang". Ini berarti keterampilan pembelajaran kooperatif siswa dominan berada pada kategori "cukup/sedang".

Hasil penelitian di atas menunjukkan adanya peningkatan hasil belajar siswa setelah model pembelajaran kooperatif tipe Team Assisted Individualization (TAI) diterapkan pada materi Sistem Persamaan dan Pertidaksamaan Linear dengan ketuntasan individu sebersar 85,19\% dan ketuntasan klasikal telah tercapai yaitu $75 \%$. Hal tersebut menegaskan bahwa pembelajaran matematika melalui model pembelajaran kooperatif tipe Team Assisted Individualization (TAI) dapat mengkombinasikan keunggulan kooperatif dan program pengajaran individual, 
membantu meningkatkan kemampuan pemecahan masalah siswa dan mengurangi anggapan banyak siswa bahwa matematika itu sulit (Megawati, 2012).

Selain itu, model pembelajaran kooperatif Tipe TAI juga dapat membantu guru agar dapat menciptakan suasana lingkungan kelas yang saling menghargai nilai-nilai ilmiah dan termotivasi untuk meningkatkan kemampuan guru mata pelajaran (Erdriani, 2016). Guru bukan lagi sebagai sosok serba tahu yang mendominasi proses belajar mengajar ataupun sebagai sumber informasi terbanyak bagi siswa, kegiatan mengajar tidak harus merupakan proses tranformasi pengetahuan dari guru kepada siswa (Kadir, 2014). Hal itu terbukti dengan hasil pengamatan dalam penelitian ini. Selama 4 kali pertemuan, tingkat kemampuan guru dalam mengelola pembelajaran menunjukkan nilai positif dan mencapai ratarata skor 3,5 (berada pada kategori Baik).

Pembelajaran yang diterapkan dengan membuat siswa bekerja dalam kelompok-kelompok kooperatif dengan status yang sejajar juga akan membangun kondisi untuk terbentuknya aktivitas positif terhadap siswa-siswa yang tercatat cacat secara akademik (Yuliantari, 2016). Hal tersebut dibuktikan oleh penelitian ini. Ketujuh aspek yang diamati memenuhi kriteria efektif, siswa sangat antusias, dan termotivasi dalam proses pembelajaran. Didapatkan persentase siswa yang melakukan aktivitas negatif dari pertemuan ke-II hingga pertemuan ke-V dalam penelitian ini menurun adalah berturut-turut $18,51 \%, 11,11 \%, 11,11 \%$ dan 3,70\%.

Begitupun dengan hasil analisis respon siswa dalam penelitian diperoleh sebanyak 94,08\% siswa memberikan respon positif terhadap pelaksanaan pembelajaran matematika melalui model pembelajaran kooperatif tipe Team Assisted Individualization (TAI). Hal ini berarti bahwa pembelajaran matematika melalui model pembelajaran kooperatif tipe Team Assisted Individualization (TAI) dapat memotivasi siswa dalam mengikuti pembelajaran.

Berdasarkan hasil analisis keterampilan pembelajaran kooperatif siswa maka diperoleh keterangan bahwa siswa yang keterampilan pembelajaran kooperatifnya berada pada kategori "baik" ada 2 siswa, yang berada pada kategori "rendah" 4 siswa, yang berada pada kategori "sangat rendah" 1 siswa, dan yang berada pada kategori “cukup/sedang” sebanyak 20 orang. Hasil tersebut sesuai dengan hasil penelitian Muliawati (2016) bahwa instruksi TAI ditemukan lebih efektif 
dibandingkan dengan metode tradisional karena siswa memiliki kesempatan untuk bekerja sama dalam tim, berbagi pandangan dan pendapat. Selain itu siswa terlibat dalam brainstorming masalah yang dibantu sikap mereka terhadap pelajaran. (Muliawati, 2016).

\section{Kesimpulan}

Berdasarkan hasil penelitian di atas, maka dapat disimpulkan bahwa model pembelajaran kooperatif tipe Team Assisted Individualization (TAI) efektif diterapkan dalam pembelajaran matematika pada siswa kelas X MAN Binamu Kabupaten Jeneponto, dimana: (1) rata-rata hasil belajar matematika siswa sebesar 85,19\% atau mencapai ketuntasan belajar secara klasikal; (2) persentase keaktifan siswa yang berkaitan dengan kegiatan pembelajaran meningkat dari pertemuan II sampai V, dan kegiatan siswa diluar skenario pembelajaran menurun dari pertemuan II sampai V; (3) Respon siswa terhadap pelaksanaan pembelajaran matematika adalah positif dengan persentase yaitu 94,08\% dan sudah memenuhi kriteria yang telah ditetapkan yaitu 75\%; (4) Keterlaksanaan pembelajaran berada pada kategori baik; dan (5) Keterampilan pembelajaran kooperatif siswa lebih banyak yang berada pada kategori sedang/cukup;

\section{Daftar Pustaka}

Aisah, S. (2015). Penerapan Metode Out Door Activity Dalam Pembelajaran Ipa Untuk Meningkatkan Hasil Belajar Siswa Sekolah Dasar. Jurnal Penelitian Pendidikan Guru Sekolah Dasar, 2(3), 1-11.

Ardila, A., \& Hartanto, S. (2017). Faktor yang mempengaruhi rendahnya hasil belajar matematika siswa mts iskandar muda batam. PYTHAGORAS: Jurnal Program Studi Pendidikan Matematika, 6(2).

J. Crawford, K. Butler-Henderson, J. Rudolph, \& M. Glowatz, 2020 COVID-19: 20 Countries' Higher Education Intra-Period Digital Pedagogy Responses Journal of Applied Teaching and Learning (JALT), 31.

Kadir, S. F. (2014). Keterampilan mengelola kelas dan implementasinya dalam proses pembelajaran. Al-Ta'dib, 7(2), 16-36. 
M. B. N. Wajdi, I. Kuswandi, U. Al Faruq, Z. Zulhijra, K. Khairudin, \& K. Khoiriyah 2020 Education Policy Overcome Coronavirus, A Study of Indonesians EDUTEC: Journal of Education And Technology, 3 2 96-106.

Megawati, Y. D. N., \& Sari, A. R. (2012). Model pembelajaran kooperatif tipe team assisted individualization (TAI) dalam meningkatkan keaktifan siswa dan hasil belajar akuntansi siswa kelas XI IPS 1 SMA Negeri 1 Banjarnegara Tahun Ajaran 2011/2012. Jurnal Pendidikan Akuntansi Indonesia, 10(1).

Muliawati, D. I., Saputro, S., \& Raharjo, S. B. (2016). Pengembangan handout berbasis Team Assisted Individualization (TAI) untuk meningkatkan prestasi belajar siswa pada materi pembuatan etanol skala laboratorium SMK kimia industri. INKUIRI: Jurnal Pendidikan IPA, 5(1), 37-44.

Noor, N., \& Munandar, I. (2019). Pengaruh Model Pembelajaran Kooperatif (Tipe TAI dan TPS) dan Aktivitas Belajar terhadap Hasil Belajar Matematika. Jurnal Ilmu Pendidikan (JIP) STKIP Kusuma Negara, 11(1), $65-75$.

Nopiyani, D., Turmudi, T., \& Prabawanto, S. (2016). Penerapan pembelajaran matematika realistik berbantuan geogebra untuk meningkatkan kemampuan komunikasi matematis siswa SMP. Mosharafa: Jurnal Pendidikan Matematika, 5(2), 45-52.

Puadi, E. F. (2020). Analisis Sikap Siswa terhadap Multimedia Pembelajaran Matematika berbasis ICT dengan Model Computer Assited Insruction (CAI). Hipotenusa Journal of Research Mathematics Education (HJRME), 3(1), 32-43.

Ramadhani, R. (2016). Pengembangan Perangkat pembelajaran matematika yang berorientasi pada model Problem Based Learning. Kreano, Jurnal Matematika Kreatif-Inovatif, 7(2), 116-122.

Upu, H., \& Djadir, D. (2016). Pengembangan Perangkat Pembelajaran Matematika Model Kooperatif Tipe Student Teams Achievement Division (STAD) dengan Pendekatan Saintifik. Pepatudzu: Media Pendidikan dan Sosial Kemasyarakatan, 9(1), 16-28.

Yuliantari, N. L. P., Meitriana, M. A., \& Zukhri, A. (2016). Implementasi Model Pembelajaran Kooperatif Tipe TAI (Team Assisted Individualization) untuk Meningkatkan Aktivitas dan Hasil Belajar Siswa pada Mata Pelajaran Kewirausahaan Kelas X SMK N 1 Sukasada, Tahun Ajaran 2015/2016. Jurnal Pendidikan Ekonomi Undiksha, 7(2).

Zhafira, N. H., Ertika, Y., \& Chairiyaton, C. (2020). Persepsi Mahasiswa Terhadap Perkuliahan Daring Sebagai Sarana Pembelajaran. Jurnal Bisnis Dan Kajian Strategi Manajemen, 4(1). 